https://doi.org/10.17816/MAJ191S1114-116

\title{
PERIPHERAL BLOOD TH17 SUBSETS IN PATIENTS WITH MULTIPLE SCLEROSIS
}

\author{
I.V.Kudryavtsev ${ }^{1}$, A.M. Petrov ${ }^{2}$, A.G. Ilves ${ }^{2}$, K.K. Mineev ${ }^{2}$, M.K. Serebriakova ${ }^{1}$, I.D. Stolyarov ${ }^{2}$ \\ ${ }^{1}$ Institute of Experimental Medicine, Saint Petersburg, Russia; \\ ${ }^{2}$ N.P. Bechtereva Institute of the Human Brain RAS, Saint Petersburg, Russia
}

\section{СУБПОПУЛЯЦИОННЫЙ СОСТАВ Т-ХЕЛПЕРОВ 17 ПРИ РАССЕЯННОМ СКЛЕРОЗЕ}

\author{
И.В. Кудрявцев ${ }^{1}$, А.М. Петров , А.Г. Ильвес ${ }^{2}$, К.К. Минеев ${ }^{2}$, М.К. Серебрякова ${ }^{1}$, И.Д. Столяров ${ }^{2}$ \\ ФГБНУ «Институт экспериментальной медицины», Санкт-Петербург; \\ ФГБУН «Институт мозга человека им. Н.П. Бехтеревой РАН», Санкт-Петербург
}

Using multicolor flow cytometry four main Th17 subsets were identified within total CCR6-expressing Th cell in peripheral blood from patients with multiply sclerosis (MS, $n=26$ ) and healthy control subjects (HC, $n=44)$. MS showed significantly higher frequencies of CCR6+DP and "classical" Th17 subsets, while the level of Th17.1 was significantly decreased if compared to HC. Correlation analysis revealed a significant relationship between the decrease of CCR6+DN Th17 subset and EDSS worsening $(r=-0.456, p=0.022)$. The area under the ROC curve (AUC) for the percentage of "classical" Th17 within CCR6+ Th as a predictor of MS was $0.948(0.882$ to $1.014, p<0.001)$ and for Th17.1 cells -0.937 ( 0.863 to $1.011, p<0.001)$. The optimal cutoff value for percentage of "classical" Th17 for predicting MS was $31.55 \%$ within CCR6 ${ }^{+}$ Th cells with $88.0 \%$ sensitivity and $95.45 \%$ specificity, while for Th17.1 $-38.66 \%$ within CCR6 ${ }^{+}$Th cells with $88.0 \%$ sensitivity and $95.45 \%$ specificity. Our data indicate that the relative numbers of "classical" Th17 and Th17.1 within $\mathrm{CCR}^{+}$Th cells were effective in discrimination between MS and HC groups.

Keywords: multiply sclerosis; flow cytometry; "classical" Th17, Th17.1; CCR4 and CXCR3.

С применением многоцветной проточной цитометрии среди CCR6-позитивных T-хелперов периферической крови больных рассеянным склерозом (MS, $n=26)$ и условно здоровых добровольцев (НС) на основании коэкспрессии CCR4 и CXCR3 были выявлены четыре основные субпопуляции Th17. Показано, что у больных MS по равнению с НC уровни «дважды-позитивных» $\mathrm{CCR} 4^{+} \mathrm{CXCR} 3^{+}$и «классических» CCR4 ${ }^{+} \mathrm{CXCR}^{-}$Th17 возрастали, а содержание CCR4-CXCR3 ${ }^{+}$Th17.1 снижалось. Обнаружена обратная взаимосвязь между увеличением уровня «дважды-негативных» CCR4-CXCR3- Th17 и баллами шкалы EDSS. C применением ROC-анализа показано, что при пороговом значении «классических» CCR $4^{+} \mathrm{CXCR} 3^{-}$Th17 $31.55 \%$ обеспечивает чувствительность и специфичность выявления больных MS 88 и $95 \%$, соответственно, тогда как для Th17.1 пороговое значение составляет $36.88 \%$ при аналогичных чувствительности и специфичности метода. Полученные результаты позволяют рассматривать «классических» Th17 и Th17.1 в качестве перспективных маркеров для выявления MS.

Ключевые слова: рассеянный склероз; проточная цитометрия; «классические» Th17, Th17.1; CCR4 и CXCR3.

Introduction. Multiple sclerosis (MS) is a demyelinating autoimmune disease of the central nervous system and the underlying mechanisms of MS are not fully understood yet [3]. A leading part in MS pathogenesis was assigned to type 1 T-helper subset (Th1) able to secrete IFNg, but, recently, more studies have been aimed at examining type $17 \mathrm{Th}$ cells (Th17) considered as one of the most promising targets for MS therapy [2]. Currently, the existence in humans of four distinct Th17-polarized CCR6 ${ }^{+}$Th subsets with differential expression of CCR4 and CXCR3, including "classical" CCR4 ${ }^{+} \mathrm{CXCR}^{-}$Th17 cells, CCR4 ${ }^{-} \mathrm{CXCR}^{+}{ }^{+}$ Th17.1 cells and two newly characterized CCR $6^{+} \mathrm{DN}$ and $\mathrm{CCR}^{+} \mathrm{DP}$ populations, was shown [5].

Material and methods. MS was diagnosed based on the McDonald criteria. All patients with relapsing-remitting form of MS $(n=26)$ underwent a neurological examination and were evaluated by the Expanded Disability Status Scale of Kurtzke

(EDSS) that varied from 1.5 to 3.5 (median 2.5). None of the patients had received immunomodulatory or immunosuppressive drugs for at least 48 month before. The healthy control (HC) consisted of 44 healthy donors matched with patients by sex and age.

The combination of monoclonal antibodies, approach design and "gating strategy" allowed to identify main Th subsets were described previously [1]. The percentages of Th17 subsets within total CCR6-expressing Th were given in Med $\left(Q_{25} ; Q_{75}\right)$. The Mann-Whitney $U$ test was used to compare MS and HC. The Spearman rank correlation was used to evaluate the relationship between the relative numbers of Th17 subsets and EDSS score. A receiver operating characteristic (ROC) analysis of the continuous parameters related to the discrimination between the groups was performed.

Results. Comparison of relative numbers of CCR6-expressing, but CXCR5-negative Th 

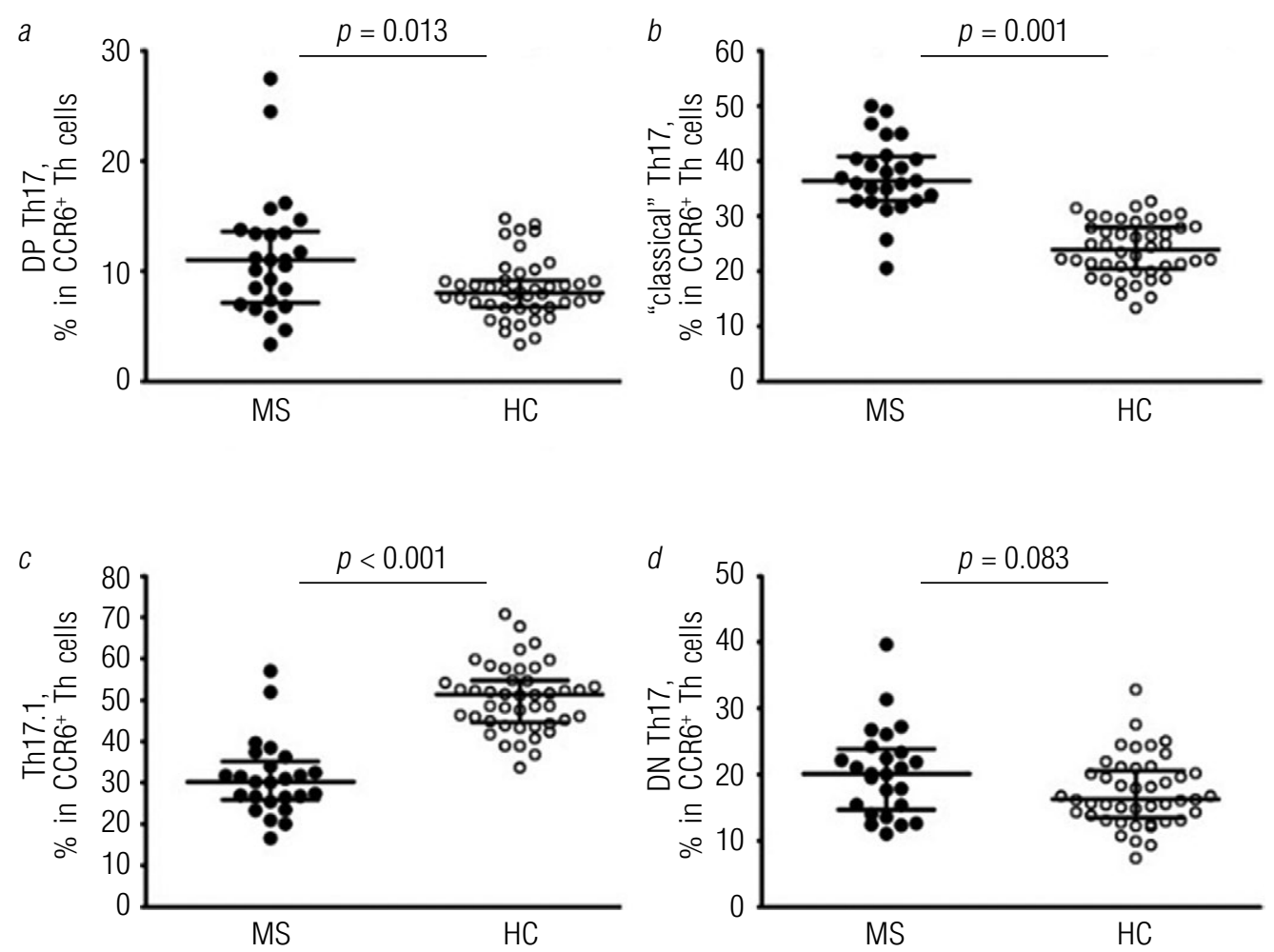

Figure. Imbalance of peripheral blood Th17 subsets in MS patients

between MS patients and $\mathrm{HC}$, indicated significantly lower frequencies of these cell in MS $(15.78 \%(14.63 ; 22.23)$ vs. $24.80 \%(20.06 ; 30.48)$, respectively, $p=0.002)$. Then, we analyzed the Th17 population in MS versus HC, based on CCR4 and CXCR3 chemokine receptors co-expression profile. This approach allowed us to specify the phenotype of "classical" Th17 cells, Th17.1 cells as well as $\mathrm{CCR}^{+} \mathrm{DN}$ and $\mathrm{CCR}^{+}$DP Th17 subsets (Figure).

Scatter plots $a, b, c$ and $d$ showing the relative numbers of $\mathrm{CCR}^{+} \mathrm{DP}$ Th17 (CXCR5 ${ }^{-}$ $\mathrm{CXCR}^{+}{ }^{+} \mathrm{CRR} 6^{+} \mathrm{CCR}^{+}$), "classical" $\mathrm{Th} 17$ (CXCR5 $\left.{ }^{-} \mathrm{CXCR}^{-} \mathrm{CCR}^{+}{ }^{+} \mathrm{CCR} 4^{+}\right)$, Th17.1 ( CXCR5 $^{-}$ $\mathrm{CXCR}^{+}{ }^{+} \mathrm{CCR}^{+} \mathrm{CCR}^{-}{ }^{-}$and $\mathrm{CCR}^{+} \mathrm{DN}$ Th17 (CXCR5 ${ }^{-} \mathrm{CXCR}^{-}{ }^{-} \mathrm{CCR} 6^{+} \mathrm{CCR} 4^{-}$), respectively, in the peripheral blood samples for MS $(n=26$, black circus) and HC ( $n=44$, white circus). Numbers represent the percentage of the indicated Th subset among total $\mathrm{CCR}^{+} \mathrm{CXCR}^{-}$Th population. Each dot represents individual subjects, and horizontal bars represent the group medians and quartile ranges (Med $\left(Q_{25} ; Q_{75}\right)$. Statistical analysis was performed with the Mann-Whitney $U$-test.

The comparison of these different Th17 subsets between MS and HC indicated significantly higher frequencies of CCR6 ${ }^{+} \mathrm{DP}$ and "classical" Th17 subsets, while the level of Th17.1 was significantly decreased in MS. These observations indicate that MS patients have the abnormal distribution of circulating Th17 cell subsets. Next, the statistical analysis revealed a significant relationship between the decrease of $\mathrm{CCR}^{+} \mathrm{DN}$ Th17 subset and EDSS worsening $(r=-0.456, p=0.022)$. Finally, the area under the ROC curve (AUC) for the percentage of "classical" Th17 within CCR6 $6^{+} \mathrm{Th}$ as a predictor of MS was 0.948 (0.882 to $1.014, p<0.001)$ and for Th17.1 cells -0.937 ( 0.863 to $1.011, p<0.001)$. The optimal cutoff value for percentage of "classical" Th17 for predicting MS was $31.55 \%$ within $\mathrm{CCR}^{+}$ Th cells with $88.0 \%$ sensitivity and $95.45 \%$ specificity, while for Th17.1 - 38.66\% within CCR6 $6^{+}$Th cells with $88.0 \%$ sensitivity and $95.45 \%$ specificity.

Conclusion. We found the imbalance between different Th17 subsets within $\mathrm{CCR}^{+}$Th from MS patients peripheral blood. The level of CCR4 ${ }^{+}$CXCR3 $3^{-}$"classical" Th17 cells was evaluated while the relative number of $\mathrm{CCR} 4^{-} \mathrm{CXCR}^{+}$ Th17.1 was decrease in MS if compared with HC. Furthermore, our data indicate that the relative numbers of "classical" Th17 and Th17.1 within CCR6 Th cells were effective in discrimination between MS and $\mathrm{HC}$ groups and these observations could let to uncover new cell markers to be used for assessing MS progression, predicting its severity and course.

\section{References}

1. Кудрявцев И.В., Борисов А.Г., Кробинец И.И., и др. Хемокиновые рецепторы на Т-хелперах различного уровня дифференцировки: основные субпопуляции // Медицинская иммунология. - 2016. T. 18. - № 3. - C. 239-250. [Kudryavtsev IV, Borisov AG, Krobinets II, et al. Chemokine receptors at distinct differentiation stages of T-helpers from peripheral blood. Medical Immunology (Russia). 2016;18(3):239-250. (In Russ.)] 
2. Кудрявцев И.В., Ильвес А.Г., Борисов А.Г., и др. CCR6-позитивные т-хелперы периферической крови при рассеянном склерозе // Цитокины и воспаление. - 2016. - Т. 15. - № 2. - С. 166-172. [Kudryavtsev IV, Ilves AG, Borisov AG, et al. CCR6-positive T helper subsets of peripheral blood in multiple sclerosis. Cytokines and inflammation. 2016;15(2):166-172. (In Russ.)]

3. Столяров И.Д., Петров А.М., Вотинцева М.В., Ивашкова Е.В. Нейроиммунология: теоретические и клинические аспекты // Физиология человека. - 2013. - Т. 39. - № 1. - C. 51-59. [Stolyarov ID, Petrov AM, Votintseva MV, Ivashkova EV. Neuroimmunology: theoretical and clinical aspects. Human Physiology. 2013;39(1):40-47. (In Russ.)]

4. Volpe E, Battistini L, Borsellino G. Advances in T helper 17 cell biology: pathogenic role and potential therapy in multiple sclerosis. Mediators Inflamm. 2015;2015:475158.

5. Wacleche VS, Goulet JP, Gosselin A, et al. New insights into the heterogeneity of Th17 subsets contributing to HIV-1 persistence during antiretroviral therapy. Retrovirology. 2016;13:59. 